\title{
Enterprise Performance and Specific Financial Sources
}

\author{
Dagmar Čámská \\ Department of Economic Studies, MIAS School of Business \\ Czech Technical University in Prague \\ Prague, Czech Republic \\ dagmar.camska@cvut.cz
}

\author{
Jiří Klečka \\ Department of Economics and Management \\ University of Chemistra and Technology Prague \\ Prague, Czech Republic \\ jiri.klecka@vscht.cz
}

\begin{abstract}
This paper is focused on specific capital sources used for financing of entrepreneurial activities. Classical sources contain equity in various forms and liabilities in a form of issued bonds, loans mainly provided by banks. In recent years there have been appearing more and more non-standard sources. These non-standard sources consist of the loans provided by individual owners, parent and daughter companies. There can be detected different incentives for this kind of behavior. Capital structure generally influences company's stability, performance and determines financial (or leverage) risk. The aim of this paper is to compare insolvent companies and companies without existential difficulties. The comparison is conducted in a way of using special financial sources. The analysis is based on the data sample obtained from the corporate database Albertina. Ratio analysis describes the capital structure. The computed capital structure is summarized and evaluated by descriptive statistics. Obtained results prove if insolvent companies tend to use these specific sources more than the rest of companies.
\end{abstract}

\section{Keywords: leverage, insolvency, Czech Republic}

\section{INTRODUCTION}

Corporate capital structure has an impact on stability, performance and it determines financial leverage and related default risk. The capital structure is usually analyzed from the point of view how many liabilities are used compared to a value of equity. Capital sources can be classified in detail. On the one hand, there are items as the equity and the liabilities, on the other hand, there can be distinguished different kinds creating these two main categories. The equity consists of different forms such as common stock, preferred stock or other initial funding completed with items generated by enterprise activities such as net income, capital surplus, retained earnings [19], [14]. The liabilities consist of issued bonds, loans provided by financial institutions and non-financial providers. In short-term view the liabilities contain also trade payables and accruals.

Non-financial loan providers can be different entities. This paper identifies specific financial sources as the loans provided by related entities. These related entities are represented by individual owners, parent and daughter companies. From the accounting point of view these sources are classified as the liabilities. It must be emphasized that a motive is not the same as in the case of the classic bank loans [6]. The bank loans are provided for a limited time period and their price is interest. In the case of the loans provided by the related entities the main incentive do not have to be interest gaining because of interest rates below market average [6]. The motive could be comparable with equity investment motive.

The aim of this paper is a comparison of specific financial sources usage in the case of insolvent enterprises and companies without existential difficulties. Obtained results could prove that the insolvent companies tend to this specific financing more. It could have serious consequences for insolvency proceedings in which the related entities can act as one creditor's group.

The paper is divided into following parts. After Introduction it comes Literature review presenting the main findings related to capital structure and Research methods which focuses on sources classification, analyzed indicators, and used methods. The most extensive part is the section Results describing a data sample and interpreting analysis outcomes. Discussion part mentions possible explanations of the observed results. Conclusion sumps up the gained results, mentions limitations and possible future research tasks.

\section{LiterATURE REVIEW AND RESEARCH METHODS}

This chapter focuses on theoretical bases. It introduces the literature review in the related field of corporate insolvencies and corporate capital structure. It has been already highlighted that the specific financial sources would be out of a main research interest. It is not a usual capital source used for financing of the entrepreneurial activities. On the other, it could be possible that this research will quantitatively confirm that the importance of these sources is indisputable in the Czech Republic. Literature review will be followed by an introduction of research methods. This part will discuss different indicators which are part of the financial statement balance sheet and which can be classified as the specific financial sources. Some items come originally from the balance sheet and some items are constructed based on these original indicators. These items will allow to describe the specific capital structure and compare the insolvent entities and the healthy enterprises.

\section{A. Literature review}

Capital structure generally describes the relationship between financing by the creditors and by the owners. There can be different sources of both kinds and there are different motives why the different sources are used. There can be found many papers discussing optimal capital structure [3], [12], and [17].

It must be emphasized that there does not exist one universal capital structure. The capital structure of real enterprises is influenced by the environment and current 
TABLE I. USED INDICATORS

Factors as enterprise's size, tangibility, industry leverage, profits and inflation were analyzed by [21] and [15]. There can be found even more untraditional (surprising) analyzed factors as internal corporate conditions represented by a structure of board of directors [1]. Capital structure is very sensitive and environment changes would affect it seriously [11].

The factors influencing capital structure do not differ in developed and developing economies [4]. The main determinants are the same but the real observed capital structure is influenced by the current conditions therefore the countries' specifics must be emphasized [4]. Capital availability is crucial if there occurs a situation that some sources become available it may result in a leverage increase by tens of per cent [13].

The leverage can affect a future corporate existence significantly. Too high leverage can even lead to insolvency. Insolvency is indicated by a lack of liquidity [20] which can be expresses short-term as inability to pay its claims or longterm as over indebtedness [22]. The insolvency is generally described as a situation when the enterprise is not able to pay its debts [8], [10], [14], and [18]. There are early warning signals that many companies reach extremely high leverage in Central Europe [9]. This can threaten the future existence and may result in the corporate insolvency as in cases [22] or [23].

This paper will analyze only one particular industry branch. It is based on findings [15] or [21] that capital structure is highly influenced by a belonging to the industry branch. Impact of the industry branch on the bankruptcy (in other words insolvency) was proved by [7] and [16]. This statement is valid generally. The capital structure of the insolvent as well as healthy enterprises differ according to the industry sector [5].

\section{B. Research methods}

The analysis will be based on ratio indicators describing enterprise capital structure. The research is focused on specific financial sources which can be provided by individual owners, parent and daughter companies. These liabilities can differ in maturity therefore there can be distinguished short-term as well as long-term financial sources. It depends on if the maturity is shorter or longer than one year. According to Czech accounting standards, these specific financial sources can be classified as:

- Payables - controlled or controlling equity;

- Payables - significant influence;

- Payables to equity holders.

All mentioned items exist in their short-term as well as long-term form. Original indicators are extracted from individual balance sheets. Additional indicators could be constructed from these original ones. Table I provides a description of the further used indicators. The sources 2, 3, and 4 are created as a sum of short-term and long-term payables of the same kind. The source 5 represents total value of the specific financial sources. The enterprises differ in their size and therefore it is necessary to relativize results. The absolute values can be compared using capital ratios whose denominator is the value of total assets (or total sources as a sum of equity and total liabilities).

\begin{tabular}{|c|c|c|}
\hline Used indicators & \multicolumn{2}{|c|}{ Description of indicators } \\
\hline Kind of indicator & Code of indicator & Content of indicator \\
\hline Original & 1 & $\begin{array}{l}\text { Total assets }=\text { Equity }+ \\
\text { Total Liabilities }\end{array}$ \\
\hline Constructed & 2 & Sum of indicators $6+9$ \\
\hline Constructed & 3 & Sum of indicators $7+10$ \\
\hline Constructed & 4 & Sum of indicators $8+11$ \\
\hline Constructed & 5 & $\begin{array}{l}\text { Sum of indicators } 2+3+4 \\
(\text { or } 6+7+8+9+10+11)\end{array}$ \\
\hline Original & 6 & $\begin{array}{l}\text { Long-term Payables - } \\
\text { controlled or controlling } \\
\text { entity }\end{array}$ \\
\hline Original & 7 & $\begin{array}{l}\text { Long-term Payables } \\
\text { significant influence }\end{array}$ \\
\hline Original & 8 & $\begin{array}{l}\text { Long-term Payables to } \\
\text { equity holders }\end{array}$ \\
\hline Original & 9 & $\begin{array}{l}\text { Short-term Payables - } \\
\text { controlled or controlling } \\
\text { entity }\end{array}$ \\
\hline Original & 10 & $\begin{array}{l}\text { Short-term Payables - } \\
\text { significant influence }\end{array}$ \\
\hline Original & 11 & $\begin{array}{l}\text { Short-term Payables to } \\
\text { equity holders }\end{array}$ \\
\hline
\end{tabular}

\section{RESULTS}

This chapter is dedicated to gained results. The results will be introduced for both analyzed groups of the companies. First group consists of the insolvent companies which declared insolvency in the period 2014-2018 according to applicable law. Second group consists of the healthy companies. The healthy companies are represented by the enterprises which created positive value added [19]. First, it will be explained how the data have been obtained for the analysis. Second, the results of the analysis will be commented

\section{A. Data sample}

The values of specific financial sources are included in balance sheets. The individual balance sheets are obtained from the paid corporate database Albertina. In the case of insolvent companies the analyzed year is one or rarely two years before the insolvency declaration. It still describes the situation when the enterprise functioned although its financial situation had been deteriorating. Second group contains the healthy companies whose financial data describe the year 2017. The year 2017 is selected for a larger data sample gaining because of the reason described below. Although it is the year 2019 and companies are obliged to report their financial situation publishing their financial statements, they tend not to do it or not to do it on time [24]. The situation is even worse for the insolvent enterprises [2].

It has a serious consequence that the used data samples have a maximum possible size. It is not possible to obtain larger data samples for a selected industry sector. The selected industry branch is CZ-NACE 25 Manufacture of fabricated metal products. The sector choice is based on its size because it is one of the largest manufacturing branch. The samples' size is described in table II. It informs about a number of companies and assets size in each group.

\section{B. Results}

This subchapter contains the summarized results for each analyzed group as well as the detailed capital structure according to different kinds of the specific sources followed by descriptive statistics informing about capital structure. 
The last part is a comparison of the insolvent and healthy companies. It will conclude if the insolvent companies use this financing more significantly than the healthy ones.

The most summarized results included in Table III prove that specific financial sources are used by the insolvent companies as well as by the healthy enterprises. Almost $39 \%$ of the insolvent sample use for their financing the specific source. The healthy companies have in their capital structure this specific source as well as but their share is lower, specifically slightly above $36 \%$.

TABLE II. DATA SAMPLE DESCRIPTION

\begin{tabular}{|l|l|l|}
\hline \multirow{2}{*}{\multicolumn{1}{|c|}{ Data sample }} & \multicolumn{2}{c|}{ Companies } \\
\cline { 2 - 3 } & \multicolumn{1}{c|}{ Insolvent } & \multicolumn{1}{c|}{ Healthy } \\
\hline Number of companies & 36 & 1,885 \\
\hline Total assets in thousand CZK & $7,077,019$ & $203,671,641$ \\
\hline Average assets in thousand CZK & 196,584 & 108,049 \\
\hline
\end{tabular}

TABLE III. COMPANIES USING SPECIFIC SOURCES

\begin{tabular}{|l|l|l|}
\hline \multicolumn{2}{|c|}{ Data sample } & \multicolumn{2}{c|}{ Companies } \\
\cline { 2 - 4 } & \multicolumn{1}{|c|}{ Insolvent } & \multicolumn{1}{c|}{ Healthy } \\
\hline Number of companies & 36 & 1,885 \\
\hline $\begin{array}{l}\text { Number of companies using specific } \\
\text { sources }\end{array}$ & 14 & 686 \\
\hline $\begin{array}{l}\text { Share of companies using specific } \\
\text { sources }\end{array}$ & $38.89 \%$ & $36.34 \%$ \\
\hline
\end{tabular}

TABLE IV. USAGE OF SPECIFIC SOURCES

\begin{tabular}{|c|c|c|c|c|}
\hline \multirow{3}{*}{$\begin{array}{l}\text { Kind of specific } \\
\text { sources }\end{array}$} & \multicolumn{4}{|c|}{ Companies } \\
\hline & \multicolumn{2}{|c|}{ Insolvent } & \multicolumn{2}{|c|}{ Healthy } \\
\hline & Absolute & Relative & Absolute & Relative \\
\hline 2 & 4 & $11.11 \%$ & 152 & $8.06 \%$ \\
\hline 3 & 1 & $2.78 \%$ & 14 & $0.74 \%$ \\
\hline 4 & 10 & $27.78 \%$ & 552 & $29.28 \%$ \\
\hline 5 & 14 & $38.89 \%$ & 685 & $36.34 \%$ \\
\hline 6 & 1 & $2.78 \%$ & 76 & $4.03 \%$ \\
\hline 7 & 1 & $2.78 \%$ & 8 & $0.42 \%$ \\
\hline 8 & 4 & $11.11 \%$ & 141 & $7.48 \%$ \\
\hline 9 & 3 & $8.33 \%$ & 104 & $5.52 \%$ \\
\hline 10 & 0 & $0.00 \%$ & 9 & $0.48 \%$ \\
\hline 11 & 8 & $22.22 \%$ & 442 & $23.45 \%$ \\
\hline
\end{tabular}

Table IV introduces the usage of the specific sources divided according their accounting classification. The table is based on the absolute numbers and the relative shares in the groups. It must be emphasized that the absolute and relative numbers describing the individual sources cannot be summed up because the companies can use more than one kind according to an accounting classification. The shortterm sources (codes 9-11) are preferred to the long-term sources (6-8). This statement is valid for both analyzed groups. The source maturity proves that this financing is used because of its flexibility. Further classifications shows that the most significant group are the payables to equity holders followed by the payables to controlled or controlling equity. On the other hand, the payables - significant influence are marginally used. The obtained results correspond with the ownership structure in the Czech Republic.

The usage of these sources still does not prove that they have an important share on the financing. Table $\mathrm{V}$ and VI work only with the subsamples that means only with the companies using specific sources for their financing. These tables consist of descriptive statistics which represent a leverage ratio. The leverage ratio is calculated as the sum of the specific sources divided by total assets or in other words by total capital sources expressed as the sum of equity and total liabilities. The healthy companies use these sources for $12.2 \%$ of their financing on average (mean). Although the displayed minimum is 0.000 , there is one company having these sources in minimal amount therefore it is shown as a zero percentage. $50 \%$ of companies have less than $4.1 \%$ on financing and therefore $50 \%$ of companies have more than $4.1 \%$ on their financing (mean). It even can be specified that $25 \%$ use it for more than $15.4 \%$ (3rd quartile). It should be also explained the maximum value. The maximum exceeds $100 \%$. It reaches the value $156.3 \%$. It can be interpreted that the company has the negative equity and therefore its total liabilities have to exceed $100 \%$. It is a possible state of the world caused by a negative net income generated in current or previous periods.

TABLE V. DESCRIPTIVE STATISTICS - HEALTHY COMPANIES - SHARE ON FINANCING

\begin{tabular}{|l|l|}
\hline \multicolumn{1}{|c|}{ Descriptive statistics } & \multicolumn{1}{c|}{ Companies } \\
\cline { 2 - 2 } Mean & 0.122 \\
\hline Median & 0.041 \\
\hline Minimum & 0.000 \\
\hline Maximum & 1.563 \\
\hline $1^{\text {st }}$ quartil & 0.005 \\
\hline $3^{\text {rd }}$ quartil & 0.154 \\
\hline Standard deviation & 0.190 \\
\hline Trim mean $(5 \%)$ & 0.106 \\
\hline
\end{tabular}

The same results can be obtained for the group of the insolvent entities (Table VI). Again these interpreted numbers are connected only with the group using the specific analyzed sources. The average share of the specific sources on the financing (mean) equals 19.6\%. The displayed minimum is $0.1 \%$. $50 \%$ of companies use less than $7.6 \%$ on financing and therefore $50 \%$ of companies use more than $7.6 \%$ on their financing (mean). It even can be specified that $25 \%$ have it for more than $20.9 \%$ (3rd quartile). The observed maximum again reaches the value over $100 \%$. The interpretation is similar this enterprise has the negative equity. 
TABLE VI. DESCRIPTIVE STATISTICS - INSOLVENT COMPANIES SHARE ON FINANCING

\begin{tabular}{|l|l|}
\hline \multicolumn{1}{|c|}{ Descriptive statistics } & \multicolumn{1}{c|}{ Companies } \\
\cline { 2 - 2 } Mean & 0.196 \\
\hline Median & 0.076 \\
\hline Minimum & 0.001 \\
\hline Maximum & 1.325 \\
\hline 1st quartil & 0.018 \\
\hline 3rd quartil & 0.209 \\
\hline Standard deviation & 0.331 \\
\hline
\end{tabular}

The results have confirmed that the specific financial sources are used and their share on financing can reach a significant proportion. The next step should be a detailed comparison of the insolvent and healthy companies. Table III has already demonstrated that the insolvent entities use these sources more than the healthy enterprises. The calculated index (the percentage of the insolvent entities compared to the percentage of the healthy entities) even shows that the insolvent enterprises use it 1.07 times more often. The indices can be calculated for each specific capital source described in Table I (the percentage of the insolvent entities compared to the percentage of the healthy entities).

TABLE VII. COMPARISON OF INSOLVENT COMPANIES WITH HEALTHY COMPANIES

\begin{tabular}{|l|l|l|}
\hline \multirow{2}{*}{ Kind of specific sources } & \multicolumn{2}{c|}{ Higher usage } \\
\cline { 2 - 3 } & \multicolumn{1}{|c|}{ Indices } & \multicolumn{1}{c|}{ Evaluation } \\
\hline 2 & 1.38 & Insolvent \\
\hline 3 & 3.74 & Insolvent \\
\hline 4 & 0.95 & Healthy \\
\hline $\mathbf{5}$ & $\mathbf{1 . 0 7}$ & Insolvent \\
\hline 6 & 0.69 & Healthy \\
\hline 7 & 6.55 & Insolvent \\
\hline 8 & 1.49 & Insolvent \\
\hline 9 & 1.51 & Insolvent \\
\hline 10 & 0.00 & Healthy \\
\hline 11 & 0.95 & Healthy \\
\hline
\end{tabular}

Table VII provides evidence about each particular financial source. The insolvent companies use in total significantly more payables to controlled or controlling equity (1.38 times) and payables - significant influence (3.74 times). On the other hands, payables to equity holders are used more by the healthy enterprises but the difference between the healthy and insolvent groups is not so high. Specifically the group of the short-term payables to equity holders overweighs the results out of favor of the insolvent companies. Dominance is not visible to each group of the financial sources. It must be noted that some groups are not used so significant as the others. The greatest informative power is provided by the share on the enterprises' financing (Tables $\mathrm{V}$ and VI). It can be repeated that the specific financial sources reach the higher share on financing for the insolvent companies compared to the healthy enterprises.

\section{DISCUSSION}

The previous chapter presented the gained results. This part will discuss received findings. The companies used more payables to controlled or controlling equity and payables to equity holders than payables - significant influence. The obtained results correspond with the ownership structure in the Czech Republic.

A comparison of the short-term sources and the longterm sources shows that the short-term ones dominate. It would support the motive of flexibility. When the enterprise needs additional sources then individual owners, parent, and daughter companies provide them quickly. Experiences talk that although these sources are classified as short-term from an accounting point of view they remain in the enterprises for the period longer than one year. This statement could be verified by the dynamic indicators which describe the development. It would be possible to verify it in the next research.

A comparison of the insolvent companies and the healthy enterprises prove that the insolvent entities use these specific sources more. It could be caused by a reason that the insolvent companies have such a poor financial performance that no one else would like to provide the additional financing sources. The only entities which are willing to lend additional money are related persons. On the other hand, it could be a way how to compare the insolvent companies. The insolvent companies using these specific sources prove that their related persons have believed that the future of the business could be saved. The insolvent companies not using these sources show that even their related entities have not trusted in a bright future. It is sometimes speculated that these companies have been driven into a bankruptcy intentionally.

\section{CONCLUSION}

This paper focused on specific financial sources. The companies do not need to use only the classical sources as the equity, the issued bonds, and the loans provided by financial institutions. In recent years the non-standard sources have occurred and their share is larger and larger. These sources consist of the loans provided by the relevant entities as the individual owners, parent and daughter companies (in financial accounting classified as payables controlled or controlling equity, payables - significant influence, and payables to equity holders). This paper proved that these specific sources are used in the significant proportion and that the insolvent companies tend to have these sources more than the healthy companies.

This research was limited to the one chosen industry sector. It is a huge limitation of the conducted research. This obstacle can be remedied by the further research. The hypothesis that the insolvent companies use the specific sources more can be verified for other industry sectors and for other countries than only the Czech Republic. From this point of view this research is just preliminary. The future research can be also conducted in different ways. First, majority of the specific sources is classified as short-term. It should be verified if these sources are really used on the short-term base. It means for a period shorter than one year or if the sources remain in the companies for a longer period 
Economic Development in the World," Ekonomický časopis, vol. 66, no. 1, pp. 28-42, 2018. the financial performance and results of insolvency proceedings could be interconnected with the share of the specific capital sources on financing. It is supposed that the insolvent companies using this financing could be in better conditions. It has serious consequences that the insolvency proceedings could achieve higher creditors' satisfaction level or faster assets monetization. There is also a huge risk that the related entities can act as one specific creditors' group and they can influence insolvency proceedings in their favor which is against other creditors' interests.

\section{ACKNOWLEDGMENT}

The paper is one of the outputs of the research project "Financial characteristics of enterprise in bankruptcy" registered at Grant Agency of Academic Alliance under the registration No. GAAA 10/2018.

\section{REFERENCES}

[1] P. Alves, E. B. Couto, and P. Francisco, "Board of directors' composition and capital structure," Research in International Business and Finance, vol. 35, pp. 1-32, 2015.

[2] J. Bokšová and M. Randáková, "Zveřejňují podniky, které procházejí insolvenčním řízením, své účetní závěrky?," Český Finanční a účetní časopis, vol. 8, no. 4, pp. 164-171, 2013.

[3] M. G. Bradley and E. H. Kim, "On the Existence of an Optimal Capital Structure: Theory and Evidence,” Journal of Finance, vol 39, pp. 857-877, 1984.

[4] L. Booth, V. Aivazian, A. Demirguc-Kunt, and V. Maksimovic, "Capital structures in developing countries," Journal of Finance, vol. 56, no. 1, pp. 87-130, 2001

[5] D. Camska, "Insolvency proceedings - analysis of enterprise leverage," in Conference proceedings of The 13th International Days of Statistics and Economics, T. Loster and T. Pavelka, Eds. Slaný: Melandrium, 2019, pp. 251-259.

[6] D. Camska, "Capital structure of insolvent companies in the Czech Republic," International Advances in Economic Research, in press.

[7] S. Chava and R. Jarrow, "Bankruptcy prediction with industry effects," Review of Finance, no. 8, pp. 537-569, 2004.

[8] S. Crone and S. Finlay, "Instance sampling in credit scoring: an empirical study of sample size and balancing," International Journal of Forecasting, vol. 28, no. 1, pp. 224-238, 2012.

[9] K. Culkova, M. Tausova, M. Muchova, L. Domarecka, and P. Taus, "Indebtedness in Chosen Industrial Sectors with Regard to the
[10] E. B. Deakin, "A discriminant analysis of prediction of business failure," Journal of Accounting Research, no. 3, pp. 167-169, 1972.

[11] H. DeAngelo and R. Roll, "How Stable Are Corporate Capital Structures?,” Journal of Finance, vol. 70, no. 1, 373-418, 2015

[12] H. DeAngelo and R. Masulis, "Optimal Capital Structure under Corporate and Personal Taxation," Journal of Financial Economics, vol. 8, pp. 3-29, 1980 .

[13] M. Faulkender and M. A. Petersen, "Does the source of capital affect capital structure?," Review of Financial Studies, vol. 19, no. 1, pp. 45-79, 2006.

[14] G. Foster, Financial Statement Analysis. New York: Prentice Hall, 1986.

[15] M. Z. Frank and V. K. Goyal, "Capital Structure Decisions: Which Factors Are Reliably Important?," Financial Management, vol. 38, no. 1, pp. 1-37, 2009.

[16] B. Ganguin and J. Bilardello, Standard \& Poor's Fundamentals of Corporate Credit Analysis. McGrew-Hill Professional, 2004.

[17] M. Harris abd A. Raviv, “ The Theory of Capital Structure,", Journal of Firnance, vol 46, pp. 297-356, 1991.

[18] P. Jardin, "Dynamics of firm financial evolution and bankruptcy prediction," Expert Systems with Application, no. 75, pp. 25-43, 2017.

[19] B. D. Jordan, R. Westerfield, and S. A. Ross, Corporate finance essentials. New York: McGraw-Hill, 2011.

[20] T. Korol, "Dynamic bankruptcy prediction models for European enterprises," Journal of Risk and Financial Management, in press.

[21] O. Oztekin, "Capital Structure Decisions around the World: Which Factors Are Reliably Important?," Journal of Financial and Quantitative Analysis, vol. 50, no. 3, pp. 301-323, 2015.

[22] J. Schönfeld, M. Kuděj, and L. Smrčka, "Financial health of enterprises introducing safeguard procedure based on bankruptcy models," Journal of Business Economics and Management, vol. 19, no.5, pp. 692-705, 2018.

[23] J. Schönfeld, M. Kuděj, and L. Smrčka, "Financial characteristics of Pre-Moratorium Companies," Politicka ekonomie, vol. 67, no.5, pp. 490-510, 2019.

[24] J. Strouhal, N. Gurtvis, M. Nikitina-Kalamae, T. W. Li, A. L. Lochman, and K. Born, "Are Companies Willing To Publicly Present their Financial Statements on Time? Case of Czech and Estonian TOP100 Companies," in Proceedings of the 7th International Scientific Conference on Managing and Modelling of Financial Risks Modelling of Financial Risks, M. Culik, Ed. Ostrava: VSB Tech Univ Ostrava, 2014, 731-738. 